\title{
GAMIFICATION DESIGN FOR TUTOR EDUCATION IN AN ONLINE COURSE
}

\author{
DESIGN DE GAMIFICAÇÃO PARA A FORMAÇÃO DE TUTORES \\ EM UM CURSO ONLINE
}

\section{DISEÑO DE GAMIFICACIÓN PARA LA FORMACIÓN DE TUTORES EN UN CURSO ENLINEA}

Carolina Costa Cavalcanti ${ }^{1}$, Andrea Filatro ${ }^{2}$, William Andrew Presada ${ }^{3}$

\begin{abstract}
This paper analyzes the use of gamification approach in tutor education, based on the development of multidimensional competencies. It checks the possibilities and limitations of the structural and content gamification approach to promote student engagement over an online course and to simulate authentic problem situations faced by tutors in their real playing field. By the use of a formative research, called design based research (DBR), a naturalistic case post factum was analyzed, in order to contribute to the improvement of the original design proposed for the course. Quantitative and qualitative data were collected in a pilot class that had 54 students enrolled. The results indicate that the combination of the two types of gamification, based on different theoretical foundations, can contribute to increase student engagement in online learning courses and to provide opportunities to transpose into practice what was theoretically discussed in the course curriculum.
\end{abstract}

KEYWORDS: Online Learning. Tutor. Design. Higher Education. Distance Education. Gamification

\section{RESUMO}

Este artigo analisa o uso da abordagem de gamificação na formação de tutores a distância, baseada no desenvolvimento de competências múltiplas. Verifica as possibilidades e limitações da abordagem de gamificação estrutural e de conteúdo para promover o engajamento dos participantes ao longo de um curso a distância e simular situações-problema autênticas enfrentadas pelos tutores em seu campo de atuação real. Pelo emprego da pesquisa formativa, um tipo de Design Based Research (DBR), empreendeu-se a análise de um caso naturalístico post factum, tendo em vista contribuir para melhoria da abordagem original. Dados quantitativos e qualitativos foram coletados em uma turma-piloto que contou com 54 estudantes inscritos. Os resultados indicam que a combinação dos dois tipos de gamificação, a despeito de terem fundamentos teóricos distintos, pode contribuir para potencializar o engajamento dos participantes em cursos a distância e para propiciar oportunidades de transpor para a prática aquilo que foi discutido teoricamente no que se refere à postura do tutor diante de situações-problema em cursos a distância.

PALAVRAS-CHAVE: Aprendizagem Online. Tutor. Design. Ensino Superior. Educação a Distância. Gamification.

\footnotetext{
${ }^{1}$ Doutora em Educação - Universidade de São Paulo (FE-USP). Professora convidada - Fundação Dom Cabral (FDC) - São Paulo, SP - Brasil. Docente - Centro Universitário Adventista de São Paulo (UNASP) - São Paulo, SP Brasil. E-mail: carolinacavalcanti.ead@gmail.com

2 Pós-doutoranda - Tecnologias da Inteligência e Design Digital - Pontifícia Universidade Católica de São Paulo (PUC-SP) - São Paulo, SP - Brasil. Doutora em Educação - Universidade de São Paulo - São Paulo, SP - Brasil. Coordenadora em design instrucional - Centro Universitário Adventista de São Paulo (UNASP) - São Paulo, SP Brasil. Docente convidada - Fundação Instituto de Administração (FIA) - São Paulo, SP - Brasil.

E-mail: afilatro@uol.com.br

${ }^{3}$ Mestre em Competências para o Mercado - Fundação Instituto de Administração (FIA) - São Paulo, SP - Brasil. Professor no MBA internacional - Fundação Instituto de Administração (FIA) - São Paulo, SP - Brasil. E-mail: bill@bikebrasil.com.br
}

Submetido em: 02/02/2017 - Aceito em: 17/09/2018

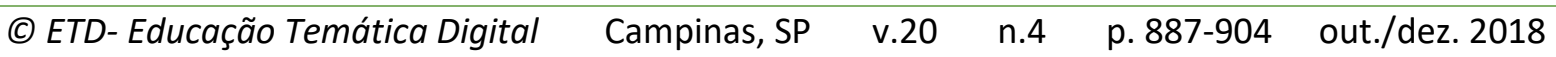




\section{RESUMEN}

Este artículo analiza el uso del enfoque de formación en gamification para tutores a distancia, basado en el desarrollo de múltiples habilidades. Comprueba las posibilidades y limitaciones del enfoque de gamification estructural y de contenido para promover la participación de los participantes en un curso a distancia y simular situaciones de problemas auténticos que se enfrentan los tutores en su campo de trabajo real. El uso de la investigación formativa, un tipo de Design Based Research (DBR), llevó a cabo el análisis de un caso post facto naturalista, con el fin de contribuir a mejorar el enfoque original. Los datos cuantitativos y cualitativos fueron recogidos en una clase de piloto que tenía 54 alumnos matriculados. Los resultados indican que la combinación de los dos tipos de gamification, a pesar de tener diferentes fundamentos teóricos, puede contribuir a mejorar la participación de los participantes en los cursos a distancia y para proporcionar oportunidades para la incorporación en la práctica de lo que se discutió en teóricamente sobre postura del tutor en situaciones y problemas enfrentados en cursos a distancia.

PALABRAS CLAVE: Aprendizaje en línea. Tutor. Diseño. Enseñanza superior. Educación a distancia. Gamification.

\section{INTRODUCTION}

For quite some time now the use of games in education has been considered an innovation. But in recent years, there has been a growing interest in a new dimension related to games, which spread in the educational field with the curious term "gamification" or "ludification".

With a relatively new theoretical framework and specific experiences reported, it draws attention when a Virtual Learning Environment (VLE) such as MoodleRooms ${ }^{4}$ provides embedded resources to put this emerging trend into practice and in an integrated manner to other elements of an online course without requiring an excessively steep learning curve, at a relatively low cost and using a transparent method for students and teachers. Due to these favorable conditions, gamification has been implemented in the course "Tutor Education on Distance Learning (DL)" and became subsequently the subject of this study.

In gamification, students do not play a whole game from start to finish, but participate in learning activities that include game elements such as engagement (including storytelling, mystery, competition, conflict, cooperation, curiosity and challenge), autonomy (including freedom to fail, rules, control, personalized pathways and safety) and progression (including levels, rewards, scoring, progressive levels of difficulty, surprise, clear goals and feedback). The term has been defined generically as the "process of using game thinking and mechanics to engage audiences and solve problems" (Zichermann \& Linder, 2013, p. 6). In instructional contexts, this dual function - audiences' engagement and problem solving - corresponds to two types of gamification as described by Kapp (2017): structural gamification and content gamification, as we see below. In fact, educational gamification has been understood as

\footnotetext{
${ }^{4}$ MoodleRooms is an enchanced version of Moodle, hosted and maintaned by Blackboard, with several improvements to the core of free code software.
}

(C) ETD- Educação Temática Digital
Campinas, SP

v. 20

n.4

p. $887-904$

out./dez. 2018 
"using game-based mechanics, aesthetics and game thinking to engage people, motivate action, promote learning, and solve problems" (Kapp, 2012, p. 10).

As we see, beyond its motivating potential, problem solving is part of the game mentality - that is, addressing a problem like a game designer, using all resources you can muster to create an engaging experience that motivates desired behaviors (Werback \& Hunter, 2012) - and it is reflected in the central concept of gamification.

At the same time, the well-known approach of problem-solving learning as an educational strategy has been adopted under the umbrella of Problem Based Learning (PBL) (Araújo \& Satre, 2009). From the proposition and description of a complex situation, students have to find ways to deal with the problem or to solve it. In this process, they get involved in a rich learning experience that allows them to articulate theoretical aspects presented in the courses' curriculum with the reality they will face in professional environments. Articulated with problem-solving learning, educational gamification has potential to stimulate persistence and active learning in online courses. 
TABLE 1 - Instructional design matrix for tutor education on a distance learning course

\begin{tabular}{|c|c|c|c|}
\hline Units & Objectives & Resources & Challenges \\
\hline Acquaintance unit & $\begin{array}{l}\text { Learn about course } \\
\text { organization, virtual learning } \\
\text { environment and also meet } \\
\text { fellow participants and tutors }\end{array}$ & Road map & $\begin{array}{l}\text { Participant's profile }+ \\
\text { Diagnostic evaluation }\end{array}$ \\
\hline $\begin{array}{l}\text { 1. Tutoring general } \\
\text { overview }\end{array}$ & $\begin{array}{l}\text { Learn about tutoring } \\
\text { fundamental concepts and } \\
\text { distinctions between } \\
\text { proactive, reactive and } \\
\text { master tutoring }\end{array}$ & $\begin{array}{l}\text { Study Guide } \\
\text { Chapter of digital book } \\
\text { Video interview }\end{array}$ & $\begin{array}{l}\text { Structured chat on } \\
\text { tutoring models }\end{array}$ \\
\hline $\begin{array}{l}\text { 2. Pedagogical } \\
\text { competencies }\end{array}$ & $\begin{array}{l}\text { Know and apply pedagogical } \\
\text { models and online tutoring } \\
\text { strategies }\end{array}$ & $\begin{array}{l}\text { Study Guide } \\
\text { Chapter of digital book } \\
\text { Video interview }\end{array}$ & $\begin{array}{l}\text { Debate on pedagogical } \\
\text { models in a discussion } \\
\text { forum }\end{array}$ \\
\hline $\begin{array}{l}\text { 3. Communicational } \\
\text { competencies }\end{array}$ & $\begin{array}{l}\text { Know and apply online } \\
\text { communication strategies }\end{array}$ & $\begin{array}{l}\text { Study Guide } \\
\text { Chapter of digital book } \\
\text { Video interview }\end{array}$ & $\begin{array}{l}\text { Interaction simulation } \\
\text { with a fictitious student } \\
\text { (Malalun Feique) via } \\
\text { email and forum }\end{array}$ \\
\hline $\begin{array}{l}\text { 4. Technological } \\
\text { competencies }\end{array}$ & $\begin{array}{l}\text { Know and apply technological } \\
\text { resources of virtual learning } \\
\text { environment }\end{array}$ & $\begin{array}{l}\text { Study Guide } \\
\text { Chapter of digital book } \\
\text { Video interview }\end{array}$ & $\begin{array}{l}\text { Technologies gymkhana } \\
\text { via glossary and forum }\end{array}$ \\
\hline $\begin{array}{l}\text { 5. Organizational } \\
\text { competencies }\end{array}$ & $\begin{array}{l}\text { Know and apply good } \\
\text { mentoring practices defined } \\
\text { by institution }\end{array}$ & $\begin{array}{l}\text { Study Guide } \\
\text { Chapter of digital book } \\
\text { Video interview }\end{array}$ & $\begin{array}{l}\text { Live interview on } \\
\text { organizational } \\
\text { competencies via Webex }\end{array}$ \\
\hline $\begin{array}{l}\text { 6. Integrated } \\
\text { competencies }\end{array}$ & $\begin{array}{l}\text { Mobilize knowledge, skills and } \\
\text { attitudes learned in authentic } \\
\text { tutoring situations }\end{array}$ & $\begin{array}{l}\text { Study Guide } \\
\text { Chapter of digital book } \\
\text { Video interview }\end{array}$ & $\begin{array}{l}\text { Tutoring Plan } \\
\text { Preparation }\end{array}$ \\
\hline $\begin{array}{l}\text { Recuperation unit } \\
\text { and course } \\
\text { conclusion }\end{array}$ & $\begin{array}{l}\text { Consolidate learning and } \\
\text { evaluate course }\end{array}$ & $\begin{array}{l}\text { Study Guide } \\
\text { Chapter of digital book } \\
\text { Video interview }\end{array}$ & $\begin{array}{l}\text { New application of the } \\
\text { diagnostic evaluation }\end{array}$ \\
\hline
\end{tabular}

Source: created by the authors

From this basic proposal, game elements were incorporated and subsequently analyzed as structural and content gamification. Students received points, badges and levels as they concluded the activities listed in the instructional design matrix and progressed through content. These resources allowed students to cumulate a well-documented registration of their achievements in a visual and accessible format.

A simple textual script set the winning rewards criteria for the production team. The criteria refers to the completion of activities considered important to advance in the course - reading study guides, watching video interviews, studying chapters of the digital book, answering questionnaires and solving challenges. These five actions, replicated in each of the 6 units with increasing levels of complexity, matched a total of 30 badges to be conquered 
throughout the course, plus 5 special badges for the expertise levels. Thus, for each set of conquered badges, the participants were awarded with a change of level - from beginner to novice to apprentice to graduate to máster as shown in table 2.

TABLE 2 - Overview of badges and expertise levels designed to the course

\begin{tabular}{|c|c|c|c|c|c|}
\hline \multirow[b]{2}{*}{ Activities } & \multicolumn{5}{|c|}{ Expertise levels } \\
\hline & $\begin{array}{c}\text { Novice } \\
\text { (6 badges) }\end{array}$ & $\begin{array}{l}\text { Beginner } \\
\text { (12 badges) }\end{array}$ & $\begin{array}{l}\text { Apprentice } \\
\text { (18 badges) }\end{array}$ & $\begin{array}{c}\text { Graduated } \\
\text { (24 badges) }\end{array}$ & $\begin{array}{l}\text { Master } \\
\text { (30 badges) }\end{array}$ \\
\hline $\begin{array}{l}\text { Reading study } \\
\text { guides }\end{array}$ & $\bar{E}^{\prime} \equiv{ }^{\prime} \equiv$ & $\bar{E}^{\prime}$ & 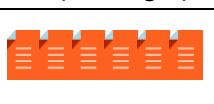 & 管 & E \\
\hline $\begin{array}{l}\text { Studying } \\
\text { chapter of } \\
\text { digital book }\end{array}$ & & 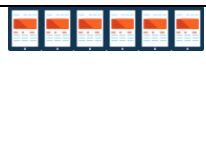 & 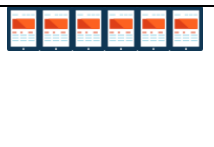 & 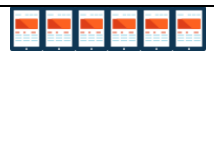 & 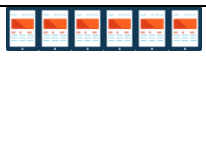 \\
\hline $\begin{array}{l}\text { Watching video } \\
\text { interviews }\end{array}$ & & & $\sin$ & कDD & $\Delta \Delta D D$ \\
\hline $\begin{array}{l}\text { Answering } \\
\text { questionnaires }\end{array}$ & & & & MMMMM & MMMMM \\
\hline $\begin{array}{l}\text { Concluding } \\
\text { challenges }\end{array}$ & & & & & prox \\
\hline
\end{tabular}

Source: adapted from Filatro, Cavalcanti, Costa (2016)

The first four types of activities could be carried out individually, while challenges followed a release schedule unit to unit, enabling the participation of the class in group activities and proactive tutoring. There was no performance ranking comparing participant's performance, since the pedagogical model adopted in the course had a a collaborative nature. At each level change, participants conquered one more badge in recognition to the conclusion of a package of similar activities, and they also had access to bonus content on the conquered set of features (for example, a comment about the role of tutors in relation to online questionnaires).

The dynamics of structural gamification were implemented using the internal VLE functionalities: participant's profile display of icons, and automatic notification system (via internal and external e-mail) informing the conquest as shown in table 3. 
TABLE 3 - Badges view from student's perspective

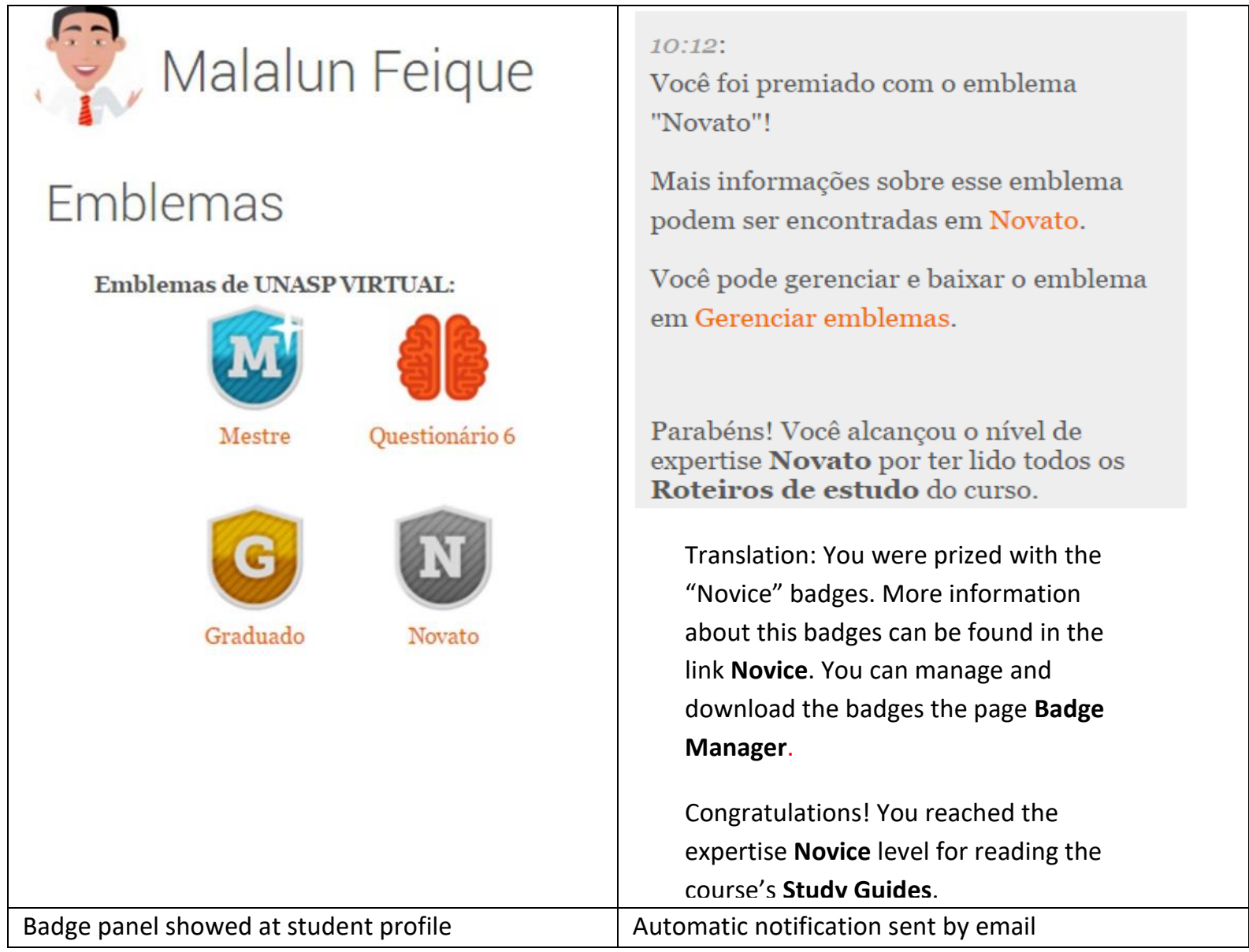

Source: adapted from Filatro, Cavalcanti, Costa (2016)

Besides that, we know that approaching problem situations as a learning strategy organizes the educational process around issues that are the starting point for meaningful and contextualized learning (Dabbagh \& Dass, 2013). It helps to articulate theory and practice as problem-situation learning approximates students to circumstances that they will encounter in real professional world. In this process, they get involved in a rich learning experience that leads them to the development of competencies.

Then, problematic situations were presented to students through Malalun Feique, a fictitious character that faced a number of difficulties during the course activities. Those problematic situations were translated into messages published by the course monitors in various spaces of VLE as shown in table 4. 
TABLE 4 - Messages published by the course monitors, on behalf of the fake student Malalun Feique, aiming to address real problematic situations faced by tutors

\begin{tabular}{|c|c|c|}
\hline Units & VLE Tools & Message \\
\hline $\begin{array}{l}\text { Acquaintance } \\
\text { Unit }\end{array}$ & $\begin{array}{l}\text { Individual } \\
\text { profile space }\end{array}$ & $\begin{array}{l}\text { I was born in Angola, but was raised in Harlem in the United States. I came } \\
\text { to Brazil five years ago. Therefore, I speak Portuguese and English fluently. } \\
\text { I have a degree in nursing. Currently, I have two jobs and still take care of } \\
\text { my youngest son, who has a serious illness and can't do anything alone. } \\
\text { I've never worked with distance education, but chose this method } \\
\text { because I can carry out the course and demanded activities at home. }\end{array}$ \\
\hline Unit 1 & Forum & $\begin{array}{l}\text { Hello, everyone! I want to tell you that I have very little time to study, } \\
\text { because I work all day, and a couple of days during the week I work the } \\
\text { night shifts at the hospital. Also, I have a son who is paraplegic and } \\
\text { depends on me for everything. I wrote to tutors because I'm thinking } \\
\text { about quitting the course because I can't keep up with the amount of } \\
\text { reading and activities proposed. It's too much for one person! }\end{array}$ \\
\hline Unit 2 & Forum & $\begin{array}{l}\text { I can't understand why we need to study this mountain of theories. I'm } \\
\text { finding this course very difficult. Can someone help me? }\end{array}$ \\
\hline Unit 3 & $\begin{array}{l}\text { Forum } \\
\text { Email }^{5}\end{array}$ & $\begin{array}{l}\text { Guys, I'm not able to answer the questionnaire this week. Does anyone } \\
\text { have the feedback of the answers? }\end{array}$ \\
\hline Unit 4 & Forum & $\begin{array}{l}\text { Tutor, I can't understand the contents of this week's lesson, which by the } \\
\text { way is poorly written. }\end{array}$ \\
\hline Unit 5 & Forum & $\begin{array}{l}\text { I'm sorry, but I do not agree with this technique to make an interview } \\
\text { appointment where everyone gets online at the same time. I'd rather do } \\
\text { my work alone, in my own way and in the time that is convenient to me. }\end{array}$ \\
\hline Unit 6 & Forum & $\begin{array}{l}\text { Guys, I want to thank everyone's patience with me. In the end, I loved } \\
\text { attending this course and learned a lot from you. I learned so much that } \\
\text { I'm even thinking of changing my name! Any suggestion? }\end{array}$ \\
\hline
\end{tabular}

Source: created by the authors

The initial presentation of the fictitious student was precisely intended to introduce him in the course so other participants would know some of his characteristics. The information about the fake student was deepened throughout the course in new publications posted in different interaction environments on the VLE. In units 1 to 6 , the fictional student participated in challenges, as he was any other student. But in unit 3, which focused on communication skills, interactions were intensified, and the fictitious student sent individual messages to students through the VLE mailbox. The challenge proposed required that students had direct contact with the fictional student, taking the role of the course tutors and being urged to respond within a certain time limit and follow the Netiquette rules and good practices of tutoring studied in the unit - as required of tutors in real work situations.

The messages sent by Malalun Feique in Unit 3 challenge, day by day, were reproduced in the next figure.

\footnotetext{
${ }^{5}$ See more details of email interaction in table 5.
} 
TABLE 5 - Problem situations proposed via email to students-tutors by fake student

\begin{tabular}{|c|c|c|}
\hline Incidence & \multicolumn{2}{|r|}{ Messages sent by fictional student } \\
\hline DAY 1 & $\begin{array}{l}\text { Message sent to ALL } \\
\text { student-tutors }\end{array}$ & $\begin{array}{l}\text { Dear Tutor, } \\
\text { As you know, I alone, have to take care of a paraplegic child and } \\
\text { time is very short to me. I still couldn't read this week's digital } \\
\text { book or watch the video lesson. I want to know if you could send } \\
\text { me a summary of the course content to make my life easier. } \\
\text { Thank you, } \\
\text { Malalun Feique }\end{array}$ \\
\hline \multirow[t]{2}{*}{ DAY 2} & $\begin{array}{l}\text { Message sent to student- } \\
\text { tutors who have } \\
\text { responded to Day } 1 \\
\text { message within } 24 \text { hours }\end{array}$ & $\begin{array}{l}\text { Dear Tutor, } \\
\text { Thank you for answering in time, but I can't open the unit } \\
\text { questionnaire. I click on the link that is indicated in the study } \\
\text { guide, but nothing happens. I need your help URGENTLY, } \\
\text { because the final deadline is tomorrow at midnight. } \\
\text { Thanks again, MALALUN }\end{array}$ \\
\hline & $\begin{array}{l}\text { Message sent to student- } \\
\text { tutors who have NOT } \\
\text { answered DAY } 1 \text { message } \\
\text { within } 24 \text { hours }\end{array}$ & $\begin{array}{l}\text { TUTOR, } \\
\text { URGENT: I CAN'T OPEN THIS UNIT'S QUESTIONNAIRE. I CLICK ON } \\
\text { THE LINK THAT IS INDICATED IN THE STUDY GUIDE, BUT } \\
\text { NOTHING HAPPENS. I NEED YOU TO HELP ME WITH URGENCY } \\
\text { BECAUSE THE FINAL DEADLINE IS TOMORROW AT MIDNIGHT. } \\
\text { MALALUN }\end{array}$ \\
\hline \multirow[t]{2}{*}{ DAY 3} & $\begin{array}{l}\text { Message sent to students } \\
\text { who have already } \\
\text { responded to DAY } 2 \\
\text { message }\end{array}$ & $\begin{array}{l}\text { TUTOR, } \\
\text { I DID'T UNDERSTAND YOUR EXPLANATION. PLEASE EXPLAIN } \\
\text { AGAIN IN A WAY THAT I CAN UNDERSTAND! AND DO IT FAST, } \\
\text { FOR GOD'S SAKE! } \\
\text { MALALUN }\end{array}$ \\
\hline & $\begin{array}{l}\text { Message sent to students } \\
\text { who had NOT responded } \\
\text { to the DAY } 2 \text { message }\end{array}$ & $\begin{array}{l}\text { TUTOR, } \\
\text { WHY DO YOU TAKE SO LONG TO ANSWER MY QUESTIONS? } \\
\text { DON'T YOU KNOW THAT MY DEADLINE IS TODAY AT MIDNIGHT? }\end{array}$ \\
\hline \multirow[t]{2}{*}{ DAY 4} & $\begin{array}{l}\text { Message sent to student- } \\
\text { tutors that did NOT } \\
\text { respond to the message } \\
\text { sent by Malalun on DAY } 3\end{array}$ & $\begin{array}{l}\text { Dear TUTOR, } \\
\text { For an effective mentoring, you need to check your mailbox } \\
\text { several times a day so you can know if students send new } \\
\text { questions. This is particularly important in the beginning of a } \\
\text { study unit and close to the deadline, when course activities are } \\
\text { supposed to be turned in. } \\
\text { Today, Malalun was left unattended and probably very } \\
\text { unpleased with that. Agility in tutoring responses [...] can make } \\
\text { all the difference in the student course results. Remember this! }\end{array}$ \\
\hline & $\begin{array}{l}\text { Message sent to student- } \\
\text { tutors who responded to } \\
\text { the message sent by } \\
\text { Malalun on DAY } 3\end{array}$ & $\begin{array}{l}\text { Dear (a) TUTOR, } \\
\text { You helped Malalun, even when he did not have discipline or } \\
\text { showed kindness towards you. } \\
\text { In fact, no matter how students behave; the important thing is } \\
\text { how you react. They need fast answers that are also accurate } \\
\text { and easy to understand. You're like a guardian angel for distance } \\
\text { learning students. This is the reason for tutoring! }\end{array}$ \\
\hline
\end{tabular}

Source: created by the authors 


\section{RESEARCH METHODOLOGY}

The research described here adopted a qualitative approach, more specifically a "formative research" - a kind of design-based research (DBR) ${ }^{6}$ that is intended to improve a particular case or a design theory for designing instructional practices or processes (Reigeluth and Frick, 1999; Reigeluth and An, 2009). It follows a case study approach as outlined by Yin (1984). More specifically, the design is typically a holistic single case - one application of the theory - created or identified. The study is exploratory and developmental in nature. And, as Reigeluth and An (2009) defend, research to improve a method or design theory is the most productive kind of research when the method or theory is in the earlier stages of its development.

Formative research can involve a designed or a naturalistic case,${ }^{7}$ depending on the researcher; it creates or picks an instance consistent with the theory, and formatively evaluates that instance to identify how each consistent element might be improved. The gamification theory instance analyzed in this paper fits the "post facto" naturalistic case study. Although the course has been designed keeping in mind a generic approach to gamification, ${ }^{8}$ "structural gamification" and "content gamification" were analyzed after the completion of the course from the Kapp categorization (2017). For these reasons, there was no opportunity to revise the case based on collected data or to try out the revision, at least not during that specific investigation. Obviously, in future editions of the course, results and conclusions highlighted here will serve as input to the review and improvement of the original proposal.

The next step in formative research is to collect and analyze descriptive and formative data, based on the presence and absence of elements in the theory and in the case. Basically, we analyzed naturalistic data registered in the Virtual Learning Environment (VLE) in the form of student response to the challenges and conclusion and performance records. Data was collected and analyzed between February and April 2016, when the course was offered to a pilot group of 54 students. The authors of this study were the invited subject matters experts (SME) and also worked as master tutors of the investigated class.

For structured gamification, collected data included quantitative records relating to the engagement of students in instructional design proposal - basically percentage of obtained activities and notes - and results of the reaction evaluation applied at the end of

\footnotetext{
${ }^{6}$ DBR is "a systematic but flexible methodology aimed to improve educational practices through iterative analysis, design, development, and implementation, based on collaboration among researchers and practioners in real-world settings, and leading to contextually-sensitve design principles and theories" (Wang \& Hannafin, 2005, p. 6-7, apud Reigeluth \& An, 2009. p. 378).

${ }^{7}$ It is important to distinguish designed cases, in which the theory is intentionally instantiated, in vivo naturalistic cases, in which the formative evaluation of the instantiation is done during its application, and post facto naturalistic cases, in which the formative evaluation of the instantiation is done after its application.

${ }^{8}$ MDA framework - meaning mechanics, dynamics, and aesthetics - presented by Zychermann \& Cunninghan (2011).
}

\begin{tabular}{|c|c|}
\hline (C) ETD- Educação Temática Digital & Camninas SP \\
\hline
\end{tabular}


the course, with pinpoint focus on the effectiveness of using badges as a motivational resource. For content gamification, collected data reflected basically the interactions between Malalun Feique and course's students. The researchers first organized all exchanged messages in one file. Then selected the answers demonstrating how interactions with Malalun Feique helped students to articulate theory learned in course content with practical problem situations found in tutorial work at a distance education course.

\section{RESULTS}

This paper aims to verify adherence of the course's gamification proposals defended by Kapp (2017), and how it stimulates student engagement to articulate theory and practice. The analysis of results is presented separately below by gamification type.

In order to evaluate the structured gamification results in the course, the student engagement data was organized as well as the points obtained (sum of the performance of automatically corrected questionnaires and performance achieved in the "manually" assessed challenges by tutors) in each unit. The most significant levels of expertise were Graduated and Master. Both depended on the cumulative conclusion of activities of other less complex levels, and both demanded more active student responses.

In the responses to the questionnaires, we note a decreasing level of engagement, but class notes showed slight increase from the first to the second unit with other units running around the average. With regards to the challenges - really practical activities, with effective development potential - there was a sharp drop from the first engagement to the second unit, with subsequent stabilization around the average, while the notes of the group oscillated from unit 3, raising up an average that would have been much lower if original trend was maintained. 
TABLE 6 - Assessment results from competence-based learning x course activities based on gamification

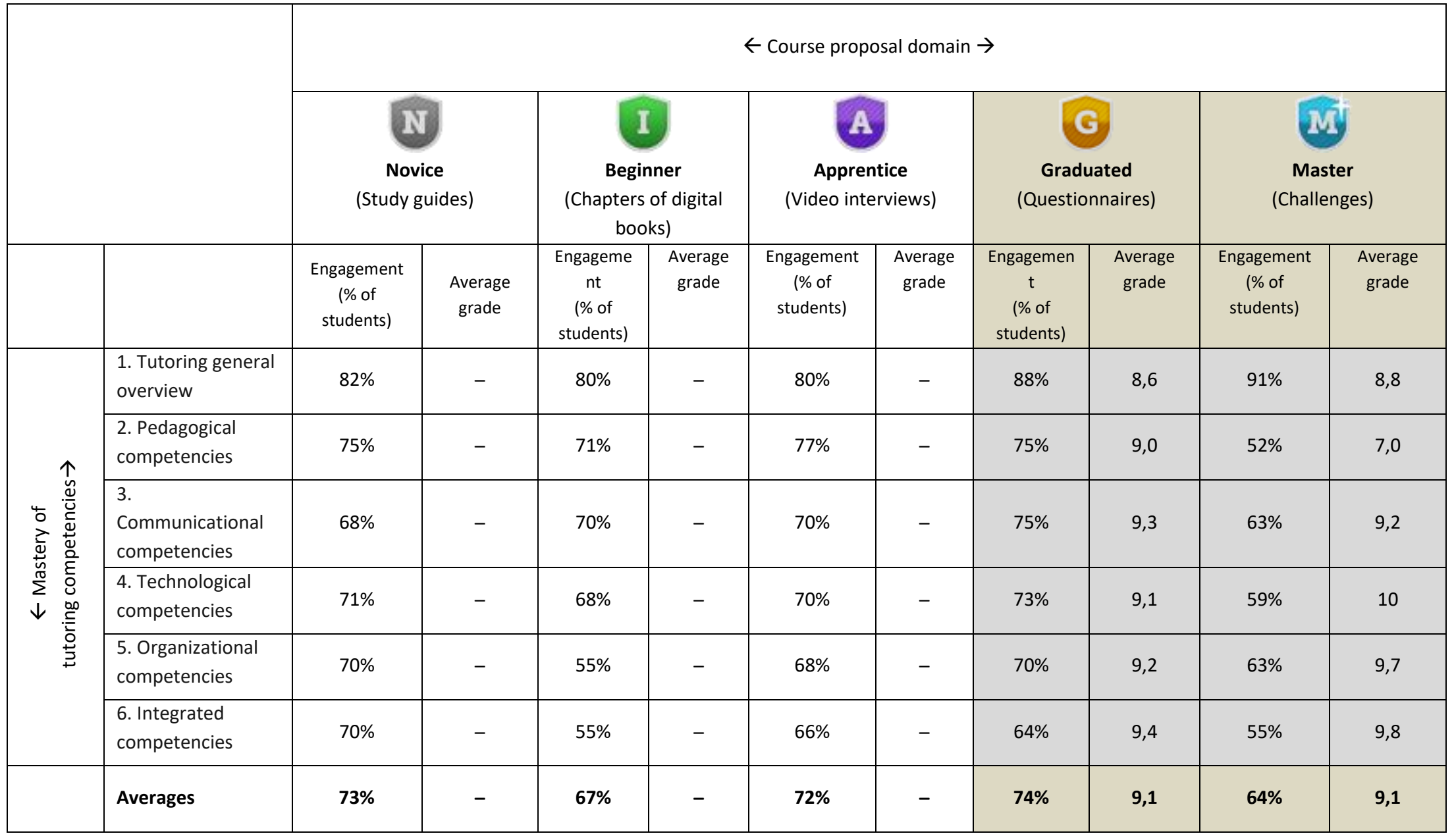

Source: adapted from Filatro, Cavalcanti, Costa (2016) 
By this quantitative analysis, we add data from a reaction evaluation (32 general questions about the course, answered by 29 participants at the end of the course). In the specific open question about gamification, "Did the badges awarded in the course represent some extra motivation for you to study online? Why or why not?", results indicate $59 \%$ of positive responses, $34 \%$ of negative responses, and $7 \%$ of conciliatory responses ("yes and no"). We highlight in the following figure some answers from each group to illustrate the participants' perception about the structural gamification proposal.

TABLE 7 - Spontaneous answers from students to an open question about badges as extra factor of motivation in distance learning

\begin{tabular}{|c|c|}
\hline Source & Student's perceptions \\
\hline Student 1 & $\begin{array}{l}\text { "YES, so much. At the beginning I wasn't paying attention, but then I began to } \\
\text { desire all [emblems]. I believe that we are used to always have a 'prize' for our } \\
\text { achievements; is already in our subconscious. I felt like in a video game, looking } \\
\text { for the 'award for each phase'." }\end{array}$ \\
\hline Student 2 & $\begin{array}{l}\text { "YES. Sure! It is very rewarding knowing that everything you do is being seen. The } \\
\text { feedback is satisfactory, and award for the effort in participatubg in the activities } \\
\text { was always a positive incentive to continue the studies." }\end{array}$ \\
\hline Student 3 & $\begin{array}{l}\text { "NO, for me emblems had no effect. The most motivated me in each unit were } \\
\text { the challenges. I learned a lot in every challenge. Each time I initiated a new unit, I } \\
\text { looked at the challenge even before the video srsrsr." }\end{array}$ \\
\hline Student 4 & $\begin{array}{l}\text { "NO, they not motivated me. I had little contact with them because they are } \\
\text { 'hidden' in my profile and do not appear visibly. If there is a way to put the } \\
\text { emblems next to the menu and let which one still remain to be conquered on the } \\
\text { shade, so I would know how many I have to win and how many already have. This } \\
\text { would motivate me more, the idea of emblems is not bad, but hidden do not help } \\
\text { much." }\end{array}$ \\
\hline Student 5 & $\begin{array}{l}\text { "NO AND YES". No, because I would do [the activities] anyway, but rather because } \\
\text { I liked to know that there was a collection of badges that accompanied the tasks." } \\
\text { " }\end{array}$ \\
\hline
\end{tabular}

Source: created by the authors

From participants' perception about the structural gamification proposal, the possibility to see their progress through the course with a visual resource as a set of badges and textual feedbacks was a great help to establish a rhythm of study over time. This strategy was applied so students would have an extra incentive to study the prepared course materials and participate in course activities. On the other hand, maybe because the students belong in the field of education, with some awareness of the limitations of behaviorism strategies, extrinsic motivational effects of structural gamification seemed null when compared to intrinsic motivation generated by content gamification, as discussed below.

Before that, we have to observe that, although the embedded badge featured in VLE has facilitated the implementation of structural gamification, one of the main difficulties encountered was the trouble students faced to locate the accumulated badges set. In addition to the immediate notification of completion of the activities and advances in levels of

$\begin{array}{llllll}\text { (C) ETD-Educação Temática Digital } & \text { Campinas, SP } & \text { v.20 } & \text { n.4 } & \text { p.887-904 } & \text { out./dez. } 2018\end{array}$


expertise, we missed a mirror interface to instructional design matrix, so that students could have a quick perception of their position in relation to all educational content and activities proposed.

As discussed earlier, a fake student conducted content gamification in the investigated course primarily through the proposition of problem situations. Malalun Feique was created to interact with the other students throughout the course units. Particularly in the challenge on unit 3, students where invited to answer messages as if they were distance learning tutors. They became student-tutors and had an opportunity to experience these situations through simulated email interactions, such as they would find in realistic tutorial environments.

The following table shows some responses sent by the student-tutors to the fake student during the week (remembering that answer timing was one of the most valued points in the discussion about the tutor's communication skills).

TABLE 8 - Student-tutors answers to fake student's messages on unit 3

\begin{tabular}{|c|c|}
\hline Incidence & Student-tutors answers to fake student's messages \\
\hline \multirow[t]{2}{*}{ DAY 1} & $\begin{array}{l}\text { Hello Malalun, } \\
\text { How are you doing? } \\
\text { I have noticed that you have been a very dedicated student and participated in many } \\
\text { course activities. Congratulations on your dedication up to here. I'll help with a tip, } \\
\text { since you told me you are experiencing difficulties in this unit: A very important part } \\
\text { of being a student in a distance learning course is time planning. } \\
\text { Plan to study on Tuesday or Wednesday so you can study of the digital book and watch } \\
\text { the video lessons. What do you think of discussing what you have learned, or discuss } \\
\text { what you learn on Thursday? Tell me what is the best time for you. } \\
\text { Count on me! }\end{array}$ \\
\hline & $\begin{array}{l}\text { Hello, Malalun, } \\
\text { I am very happy that, although you are in the midst of many difficulties, you have } \\
\text { understood the importance of always improving your knowledge and decided to } \\
\text { participate in this course. I feel that if I sent you a summary of the unit content, I would } \\
\text { deprive you from an important learning experience. All materials were prepared } \\
\text { considering that accessing them would enhance your learning experience. Reading a } \\
\text { summary would not meet that goal. } \\
\text { There are only } 4 \text { more weeks to the conclusion of this course. Try to make an even } \\
\text { bigger effort, to catch up on the study of the late stuff and to participate in the course } \\
\text { activities. } \\
\text { I know this will help you achieve your desire to become a distance-learning tutor and } \\
\text { to be able to spend more time with your son. } \\
\text { I am available to help you in any way possible to achieve that goal! }\end{array}$ \\
\hline DAY 2 & $\begin{array}{l}\text { Hello Malalun! } \\
\text { You don't have to thank me. I'm here to help! I'll check what is going on and try to } \\
\text { solve the problem. I am sending an email to the course's technical support so they can } \\
\text { check what actually happened. } \\
\text { Please let me know if the problem is not solved, and if you prefer you can send an } \\
\text { email directly to the LVE support account. I just want to follow this case until } \\
\text { everything is resolved. } \\
\text { Remember that I'm available do help you! }\end{array}$ \\
\hline
\end{tabular}




\begin{tabular}{|l|l|}
\hline & Hello Malalun, \\
Use this link to access the questionnaire: \\
https://unasp.mrooms.net/mod/quiz/view.php?id=20533. I recommend using \\
Google Chrome browser, to avoid compatibility problems, which can be downloaded \\
from the following link: https://www.google.com.br/chrome/browser/desktop/ \\
Get ready to answer the questionnaire, studying the material in the VLW. Take it easy \\
when answering the questionnaire because there is no time limit to do it. Remember \\
that you still have two chances to answer the whole questionnaire. \\
If you still can't access the questionnaire, please feel free to contact me!
\end{tabular}

Source: created by the authors

In the replies sent by the student-tutors, it was clear that they understood aspects related to communication skills addressed in the course content. The materials prepared for unit 3 enhanced the role of the tutor as motivator for students to have success in online distance learning courses.

It is important to remember that, in next units, the fictitious student continued to interact in forums, and only revealed who he was in the last unit of the course, with a message inviting students to suggest a new name for Malalun Feique. Some suggestions are reproduced in the following figure. 
use of structural gamification had the basic purpose to encourage the engagement of participants in the proposed activities, serving indirectly - not directly - to the development of competencies.

For some, the coexistence of the two types of gamification in a single proposal for instructional design may seem too eclectic. However, following the perspective of formative assessment adopted so far, we can say, along with Reigeluth \& An (2009) that "paradigm wars", can be counterproductive for instructional theory. In fact, holding multiple theoretical perspectives provides a practitioner with a wide variety of instructional tools. In that sense, the use of functional contextualism ${ }^{9}$ is a helpful framework for building instructional theory.

This applies mainly when there is a need to articulate theory learned in course content with the expected performance in the real professional context. For the specific theme of this paper, structural gamification is intended to provide reinforcement and extrinsic motivation over longer periods of time. Instructors can gamify course structure by providing recognition for attainments in the form of points, badges, trophies, and so forth. All of this would seem to work well with personalization of instruction as one could imagine a course with multiple content paths that students can navigate in their own pace. It is something that instructional designers can do, without a deep knowledge of subject domain, supporting subject matter experts (SME) or event-dedicated teachers.

Content gamification, on the other hand, is intended to generate intrinsic motivation and to foster feelings of autonomy, competence and relatedness. For that, teachers and SMEs, with support of instructional designers, can gamify content by incorporating game elements such as story, challenge, characters/avatars, mystery and so forth. Furthermore, in this proposition, the content gamification was articulated for role-playing and stimulated social learning, as participants applied and shared their knowledge with their peers, and observed in the LVE public areas such as chat and forums, how their peers reacted to problem situations imposed by the fictitious student.

The creation of a character-problem brought a playful and creative perspective, which is also a motivational element of games applied to the proposed instructional design. Finally, the "revelation" of Malalun Feique character as catalyst for problematic situations provided a metacognitive and meta-analysis of behavioral activity, so the student-tutors were able to see their own reactions in a simulation of tutorial interactions. They were able, therefore, to articulate theory and practice by the use of structural and content gamification design strategies used in Tutor Education on Distance Learning course.

\footnotetext{
${ }^{9}$ Funcionalist view of design theory that advocates using whatever works (functions better) and a contextual view that recognizes that what works best will vary from one situation to other (Reigeluth and An, 2009, p. 369).
}

(C) ETD- Educação Temática Digital
Campinas, SP

v.20

n.4

p. $887-904$

out./dez. 2018 


\section{REFERENCES}

BERGE, Zane. Facilitating computer conferencing: recommendations from the field. Educational Technology. v. 35, n.1, p. 22-30, 1995.

CAVALCANTI, Carolina Costa; FILATRO, Andrea. Problem solving learning to articulate theory and practice in tutors for distance education. 2016 International Conference Problem BasedLearning and Active Methodologies. São Paulo, Brazil: September 8-10, 2016.

COLLINS, Mauri; BERGE, Zane. Facilitating interaction in computer mediated online courses. Proceedings of the FSU/AECT Conference on Distance Learning. Tallahassee, FL, June 20-23, 1996.

DABBAGH, Nada; DASS, Susan. Case problems for problem based pedagogical approaches: a comparative analysis. Computers and Education, v. 64, p. 161-164, 2013.

FILATRO, Andrea; CAVALCANTI, Carolina Costa; COSTA, Jonathan. Uso de recursos de gamificação embarcados em AVA. XXII Congresso Internacional de Educação a Distância. Águas de Lindoia, Brazil: ABED, 2016.

JONASSEN, David. Learning to solve problems: a handbook for designing problem-solving learning environment. New York, NY: Routledge, 2011.

KAPP, Karl. Gamification Designs for Instruction. In: REIGELUTH, Charles M. et al. (Org.) Instructional design theories and models: the learner-centered paradigm of education. Vol. IV. New York, NY: Routledge, 2017.

REIGELUTH, Charles. M.; FRICK, Theodore (Org.). Formative research: a methodology for creating and improving design theories. In: REIGELUTH, Charles M. Instructional-design theories and models: a new paradigm of instructional theory. Vol. II. Mahwah, NJ: Lawrence Erlbaum, 2013, c1999.

REIGELUTH, Charles M.; AN, Yun-Jo. Theory building. In: REIGELUTH, Charles M.; CARRCHELLMAN, A. A. (Org.) Instructional-design theories and models: building a common Knowledge Base. Vol. III. New York, NY: Routledge, 2009.

RYAN, Richard. M.; Deci, Edward L. Self-determination theory and the facilitation of intrinsic motivation, social development, and well-being. American Psychologist, v. 55, p. 68-78, 2000.

VOORHEES, Richard. M.; VOORHEES, Alice Bedard. Principles for Competency-based education, 2017. In: Reigeluth, Charles. M. et al. Instructional design theories and models: the learner centered paradigm of education. Vol. IV. New York, NY: Routledge, 2017.

WERBACH, Kevin; HUNTER, Dan. For the win: how game thinking can revolutionize your business. Philadelphia, PA: Wharton Digital, 2012. 
YIN, Robert K. Case study research design and methods. Beverly Hills, CA: Sage, 1984.

ZICHERMANN, Gabe; CUNNINGHAM, Christopher. Gamification by design. North Sebastopol, CA: O’Reilly Media, 2011.

ZICHERMANN, Gabe; Linder, Joselin. The gamification revolution: how leaders leverage game mechanics to crush the competition. McGraw-Hill Education, 2013.

\section{Acknowledgements}

This research was support by Education and Design research group at UNASP Campus Virtual, Brazil. The data presented, the statements made, and the views expressed are solely the responsibility of the authors. 